\title{
RESISTANCE TRANSFER IN MIXED CULTURES OF STAPHYLOCOCCUS AUREUS
}

\author{
J. A. Meijers, K. C. WinkLer and E. E. Stobberingh \\ (With a mathematical appendix by P. P. Schrauwen) \\ Laboratory of Microbiology, State University, Catharijnesingel 59, 3511 GG Utrecht, \\ The Netherlands
}

SummaRY. Transfer of resistance markers was regularly observed in mixed cultures of pairs of constructed strains of Staphylococcus aureus. This transfer was shown to be due to general transduction and required a lysogenic donor strain, carrying a transducing phage of serotype B and a transducible plasmid, and an acceptor strain without either strong restriction or an incompatible plasmid. Transfer was sometimes bidirectional when both strains carried a transducing phage. Unidirectional transfer occurred when the acceptor strain was immune. When the acceptor was sensitive to the donor phage, reversed transfer of a marker from the acceptor to the donor could take place.

The kinetics of transfer are governed by the rate of phage production, the rate of phage adsorption and the frequency of transduction. A mathematical model has been developed to describe the interplay of these factors. The numbers of transductants observed in mixed cultures agreed with those expected from the model.

Transfer was also observed in mixed cultures of constructed strains and wild-type strains. Transfer between wild-type strains is also possible, but was not observed in many combinations because of lack of transducing phage, strong restriction or other factors.

Transfer was also observed in local lesions in mice infected with two strains and in mixtures inoculated on to human skin.

\section{INTRODUCTION}

In Staphylococcus aureus, transfer of genetic markers in vitro is possible by general (Ritz and Baldwin, 1958) or specific (Lacey, $1971 a$ and $b$ ) transduction, by transformation and by transfection. Transfer of resistance markers by general transduction in vivo (Jarolmen, Bondi and Crowell, 1965) required very large quantities of phage, which apparently excludes general transduction as a natural mechanism of transfer. Transfer in vivo by specific transduction has been obtained in mice (Novick and Morse, 1967) and on human skin (Lacey, $1971 b$; Lacey and Richmond, 1974) with strains carrying a phage containing a specific marker in the phage genome. 
In mixed cultures, marker transfer has been observed with special strains. The low concentration of free phage (Lacey, 1971b) or the absence of inhibition by antiphage serum (Witte, 1977) were used as arguments against transduction as a possible mechanism of transfer.

Some favourable experiments with mixed cultures of wild-type strains prompted us to construct lysogenic, restriction-deficient strains, with suitable resistance plasmids. Within mixtures of these strains transfer was regularly observed. This has allowed the mechanism and kinetics of transfer to be studied and some requirements for transfer in mixed culture to be defined.

\section{MATERIALS AND METHODS}

Strains. The strains of $S$. aureus studied are listed in table I.

Culture media. Nutrient Broth (Difco) with $\mathrm{NaCl} 5 \mathrm{~g}$ and $\mathrm{CaCl}_{2} 87.6 \mathrm{mg} / \mathrm{L}$ was used throughout. For solid media $12 \mathrm{~g}$ of Davis Agar was added per L. Incubation was at $37^{\circ} \mathrm{C}$. Selection plates contained, in $\mu \mathrm{g} / \mathrm{ml}$, penicillin (Pc) $0 \cdot 1$, tetracycline (Tc) 5 , chloramphenicol (Cm) 15, erythromycin $(\mathrm{Em}) 10$ or kanamycin $(\mathrm{Km}) 5$.

Other materials. Human gammaglobulin was obtained from the blood transfusion service, DNAase from Boehringer (Mannheim). Antisera against phage were raised in rabbits.

Phages were those of the international phage-typing system and phages isolated from lysogenic strains, $L_{10}$ indicating a lysogenic phage from strain $M_{10}$. Phage techniques were as described by Adams (1959) and by Blair and Williams (1961), but phage typing was done at $37^{\circ} \mathrm{C}$ to reduce restriction. Free phages in lysogenic cultures were counted directly as plaque-forming units (pfu) on antibiotic-resistant indicator strains on plates containing an antibiotic by which the lysogenic cocci were inhibited and did not cause plaques. Lysogenic phages were induced by culturing the strain in nutrient broth with mitomycin C (Kyowa Hakko Kogyo Co, Tokyo) 0.5 $\mu \mathrm{g} / \mathrm{ml}$ on a shaker for $5 \mathrm{~h}$. Supernates were filtered through Millipore filters (pore size $0.45 \mu \mathrm{m}$, diameter $25 \mathrm{~mm}$ ) and titrated. The restriction-deficient mutants $80 C R_{3}$ and $879 R_{4}$ were the most suitable indicator strains.

Defective lysogenic strains were isolated after mutagenesis with ethylmethane sulphonate (Koch Light) as described by Stobberingh and Winkler (1977). The surviving population was washed and suspended in broth. After incubation for $3 \mathrm{~h}$ at $37^{\circ} \mathrm{C}$ for expression, mitomycin C $(0.5 \mu \mathrm{g} / \mathrm{ml})$ was added to induce complete phages. After further incubation for $3 \mathrm{~h}$ the population was plated and single colonies spotted on a phage-sensitive indicator strain. Colonies that did not cause a lytic zone were tested for immunity and for phage production in pure culture with and without mitomycin C. Strain $80 \mathrm{CR}_{3}(\mathrm{~d} 71)$ indicates a strain with a defective phage 71.

Adsorption coefficients $\left(\mathrm{k}\right.$ in $\mathrm{cm}^{3} / \mathrm{min}$ ) were determined with viable bacteria, mixing $1 \mathrm{ml}$ of broth containing $3 \times 10^{8}$ bacteria with $1 \mathrm{ml}$ containing $10^{9} \mathrm{pfu}$ of phage. Phage was titrated after incubation for 3,6 and $12 \mathrm{~min}$.

The fraction of cells lysed during the growth of lysogenic strains was designated " $a$ " and was determined by dispensing $0 \cdot 3-\mathrm{ml}$ portions of a dilution containing 60-300 cocci into each of 55 tubes. The number of colony forming units (cfu) and pfu in each of five tubes was counted immediately and the final number of pfu after incubation for 30 min was counted in the remaining tubes. The number of tubes in which the phage titre had not increased was used to calculate the mean number of bursts per tube from the Poisson distribution. The number of tubes expected to contain 1,2 or 3 bursts was also calculated and verified from the phage counts. The fraction " $a$ " is the total number of bursts divided by the total number of cells in 55 tubes. The mean burst size was calculated from the total increase in the number of pfu divided by the number of bursts.

Transduction was performed as described by Stobberingh and Winkler (1977). In all experiments the phage pattern of a representative number of transductants was determined. The 
frequency of transduction (FOT) is defined as the number of transductants (T) divided by the added number of pfu.

Mixed cultures were prepared by inoculating $0.2 \mathrm{ml}$ of an overnight culture or $0.2 \mathrm{ml}$ of a culture in the exponential phase of both partners into $20 \mathrm{ml}$ of broth. The mixture and single-culture controls were incubated while being shaken in a waterbath. The total number of cfu was determined by the method of Miles, Misra and Irwin (1938). Growth rates $(\mu)$ were determined from viable counts because it has been shown (Strasters and Winkler, 1966) that the mean clump size does not vary much during exponential growth in shaken cultures.

Recombinants were counted on selection plates and a representative number was phage typed to determine the direction of transfer. The frequency of transfer $(\mathrm{Y})$ was the number of recombinants expressed as a fraction of the total population.

Markers used in constructed strains. The Tc plasmid (2.7 megadalton) was derived from strain $\mathrm{MR}_{6}$, transduced to strain 57 for purification and from this strain to the lysogenised strains. The $\mathrm{Cm}$ plasmid was derived from strain $\mathrm{MR}_{18}$ by the same procedure. The Pc plasmid (18-20 megadalton) coding for penicillinase of serotype $A$ was derived from strain $M_{6}$. It could also be transduced to the restriction-deficient mutant strain $3 \mathrm{AR}_{1}$ of phage group II in which it does not occur naturally.

Experiments in mice. Two strains suspended in $1 \%(\mathrm{w} / \mathrm{v})$ cotton dust in $2 \%(\mathrm{w} / \mathrm{v})$ carboxymethylcellulose in saline were injected under the skin of the back of inbred female BALB/c mice. The numbers of cocci inoculated are shown in table VII. After $72 \mathrm{~h}$ local lesions developed and the mice were killed. The skin over the lesions was opened and the contents of the lesion harvested with a small bone curette, 14-21 $\mu \mathrm{L}$ per lesion being collected. The material was resuspended in broth and used for viable counts and detection of transductants.

Experiments on human skin. Areas of $2 \mathrm{~cm}^{2}$ of human skin were stripped six times with vinyl tape, disinfected with alcohol and defatted with acetone. Cocci of two strains (see table VII) were inoculated in $10-\mu \mathrm{L}$ volumes of broth on the area, which was then covered with a water-impervious label fixed with adhesive tape. After various intervals the adhesive tape was removed and a small amount of broth (Singh, Marples and Kligman, 1971) was introduced between label and skin. The area was rubbed with a plastic rod, the fluid collected and used to count the total number of $S$. aureus and of recombinants. Contact plates were also used to detect recombinants in the flora adhering to skin and label.

\section{RESULTS}

\section{Mixed cultures with wild type strains}

Combinations of multiply resistant strains (table I) differing in two resistance markers were tested in mixed culture. After incubation for 5 and $24 \mathrm{~h}$, several yielded recombinants which generally had the phage pattern of one strain, suggesting unidirectional transfer. Mixtures yielding recombinants often contained one of the strains $\mathrm{MR}_{3}, \mathrm{MR}_{10}$ or $\mathrm{MR}_{11}$, which apparently were suitable donor strains (table II). After mitomycin-C induction the lysates of these strains could be used for transduction to strains $\mathrm{MR}_{13}, \mathrm{MR}_{18}$ and 57 with frequencies ranging from $10^{-3}$ to $10^{-5}$. Phage could not be isolated from the transducing lysate of strain $\mathrm{MR}_{3}$ but phages $\mathrm{L}_{10}$ and $\mathrm{L}_{11}$ could be propagated on strain 57. Phage $L_{11}$ is a transducing phage of serotype $B$, as is phage $L_{10}$, though the latter contained additional antigens and crossreacted with other sera.

When lysogenised with phage $\mathrm{L}_{10}$ or $\mathrm{L}_{11}$ the antibiotic resistance of strain 57 did not alter, thus excluding the presence of a resistance marker in the genome of the phage used for lysogenisation. 
TABLE I

Properties of the strains

\begin{tabular}{|c|c|c|c|}
\hline $\begin{array}{l}\text { Strain no. } \\
\text { (reference) }\end{array}$ & Phenotypic properties* & Phage pattern $\dagger$ & Lysogeny $\ddagger$ \\
\hline $\begin{array}{l}\text { Non-lysogenic strains } \\
57 \text { (Winkler et al., 1965) } \\
80 C \text { (Asheshov and Winkler, 1966) } \\
879 \text { (Winkler and Grootsen, 1961) } \\
\text { PS 3A (NCTC8319) }\end{array}$ & $\begin{array}{l}\text { Pc }(C d) \\
\text { cryptic plasmid } \\
\ldots\end{array}$ & $\begin{array}{l}\text { I, III } \\
\text { I } \\
\text { II } \\
\text { II }\end{array}$ & $\begin{array}{l}\cdots \\
\cdots \\
\cdots\end{array}$ \\
\hline $\begin{array}{l}\text { Restriction-deficient mutants } \\
80 \mathrm{CR}_{3} \\
3 \mathrm{AR}_{1} \\
879 \mathrm{R}_{4}\end{array}$ & $\begin{array}{l}r_{80 A^{-}}^{-} m_{80 A}^{-}, r_{80 B}^{-} m_{80 B}^{+} \\
r_{I^{-}}^{-} m_{I I}^{-}, r_{3 A}^{+} m_{3 A}^{+} \\
r^{-} m^{+}\end{array}$ & $\begin{array}{l}\text { I, II, III } \\
\text { I, II, III } \\
\text { I, II, III }\end{array}$ & $\begin{array}{l}\cdots \\
\cdots \\
\cdots\end{array}$ \\
\hline $\begin{array}{l}\text { Wild-type strains } \\
\mathrm{MR}_{3} \\
\mathrm{MR}_{6} \\
\mathrm{MR}_{8} \\
\mathrm{MR}_{10} \\
\mathrm{MR}_{11} \\
\mathrm{MR}_{13} \\
\mathrm{MR}_{18}\end{array}$ & $\begin{array}{l}\mathrm{Pc}, \mathrm{Cd} \mathrm{Cm} \mathrm{Km} \mathrm{Sm} \mathrm{Su} \\
(\mathrm{Pc}, \mathrm{Cd})(\mathrm{Tc})(\mathrm{Em}) \mathrm{Sm} \mathrm{Su} \\
\mathrm{Pc}, \mathrm{Cd}(\mathrm{Tc}) \\
(\mathrm{Pc}, \mathrm{Cd})(\mathrm{Em})(\mathrm{Tc}) \mathrm{Km} \mathrm{Su} \\
\mathrm{Pc}, \mathrm{Cd} \mathrm{Em} \mathrm{Tc} \mathrm{Km} \mathrm{Sm} \mathrm{Su} \\
\mathrm{Pc}, \mathrm{Cd} \mathrm{Cm} \mathrm{Tc} \mathrm{Sm} \mathrm{Su} \\
\mathrm{Pc}, \mathrm{Cd} \mathrm{Cm} \mathrm{Tc} \mathrm{Km} \mathrm{Sm} \mathrm{Su}\end{array}$ & $\begin{array}{l}\mathrm{NT} \\
6 / 7 / 47 / 53 / 54 / 83 \mathrm{~A} / 88 / 85 \\
53 / 75 / 85 \\
29 \\
\mathrm{NT} \\
88 / 94 \\
29 / 52 / 52 \mathrm{~A} / 80-42 \mathrm{E} / 53 / 54 / 77 / 84\end{array}$ & $\begin{array}{l}\text { ND } \\
\text { ND } \\
+ \\
\text { B } \\
\text { B } \\
\text { ND } \\
+\end{array}$ \\
\hline
\end{tabular}

* Markers in parentheses are located on plasmids, underlined marker is chromosomal. $\mathrm{Pc}, \mathrm{Tc}, \mathrm{Cm}, \mathrm{Em}$, $\mathrm{Km}, \mathrm{Cd}$, Su and Sm indicate resistance to penicillin, tetracycline, chloramphenicol, erythromycin, kanamycin, cadmium sulphate, sulphonamide and streptomycin, respectively.

$\dagger$ For the non-lysogenic and restriction-deficient strains, I, II and III indicate sensitivity for all phages of that phage group. NT $=$ not typable.

$\ddagger N D=$ not detected; $B=$ phage of serotype B present; $+=$ phage present reactive with anti-A and anti-B serum.

TABLE II

Transfer in mixed cultures

\begin{tabular}{|c|c|c|c|c|}
\hline $\begin{array}{c}\text { Experiment } \\
\text { no. }\end{array}$ & Strain 1 & Strain 2 & $\begin{array}{c}\text { Selection } \\
\text { for } \\
\text { recombinants }\end{array}$ & $\begin{array}{l}\text { Number of } \\
\text { recombinants } / 10^{9} \mathrm{cfu} \\
(\text { after } 24 \mathrm{~h})\end{array}$ \\
\hline $\begin{array}{c}\text { Wild-type strains } \\
1 \\
2 \\
3\end{array}$ & $\begin{array}{l}\mathrm{MR}_{3} \\
\mathrm{MR}_{10} \\
\mathrm{MR}_{11}\end{array}$ & $\begin{array}{l}\mathrm{MR}_{6} \\
\mathrm{MR}_{13} \\
\mathrm{MR}_{18}\end{array}$ & $\begin{array}{l}\mathrm{Tc}, \mathrm{Km} \\
\mathrm{Em}, \mathrm{Cm} \\
\mathrm{Em}, \mathrm{Cm}\end{array}$ & $\begin{array}{l}300 \\
100 \\
500\end{array}$ \\
\hline $\begin{array}{c}\text { Constructed strains } \\
4\end{array}$ & $879(71)(\mathrm{Tc})$ & $879 R_{4}(71)(C m)$ & $\mathrm{Tc}, \mathrm{Cm}$ & 2000 \\
\hline $\begin{array}{l}5 \\
6 \\
7 \\
8\end{array}$ & \multicolumn{2}{|c|}{$\begin{array}{l}\text { strain with DNAase }(40 \mu \mathrm{g} / \mathrm{ml}) \\
\text { strain with } \mathrm{IgG}(16 \mathrm{mg} / \mathrm{ml}) \\
\text { strain with anti-phage serum }(10 \%, \mathrm{~K}=17) \\
\text { strain without } \mathrm{Ca}^{+}+\text {ions }\end{array}$} & $\begin{array}{l}\text { Tc, } \mathrm{Cm} \\
\text { Tc, } \mathrm{Cm} \\
\text { Tc, } \mathrm{Cm} \\
\text { Tc, } \mathrm{Cm}\end{array}$ & $\begin{array}{r}1800 \\
20 \\
100 \\
<1\end{array}$ \\
\hline
\end{tabular}

$\mathrm{K}=$ neutralisation coefficient of the anti-phage serum. Other abbreviations as in table I. 


\section{Mixed cultures of constructed strains}

The non-lysogenic strains 57 and 879 and the restriction-deficient mutant strains $879 R_{4}, 3 A R_{1}$ and $80 C R_{3}$ were lysogenised with transducing phages 71 , $\mathrm{L}_{10}, \mathrm{~L}_{11}$ and others. The lysogenic strains kept their normal sensitivity to the relevant antibiotics; this excluded specialised transduction. Extrachromosomal resistance markers were introduced by transduction.

With such strains the mechanism of transfer could be studied. Tables II, III and IV show that transfer regularly took place in mixed cultures of these strains. DNAase did not reduce transfer (table II, expt. no. 5). Human IgG, which inhibits phage adsorption probably because it contains antibacterial antibodies (Nordström, Forsgren and Cox, 1974), also reduced transfer. The inhibition of transfer by anti-phage-B serum is also shown in table II and in fig.

3 . The presence of $\mathrm{Ca}^{++}$ions was obligatory.

These experiments suggest transfer by general transduction.

\section{Conditions for transfer}

The hypothesis of general transduction as the mechanism of transfer requires, first, a donor strain lysogenic for a transducing phage of serogroup B and carrying a (plasmid) marker transducible with sufficient frequency by that phage and, second, an acceptor strain without (strong) restriction for the donor modification (Stobberingh and Winkler, 1977), without an incompatible plasmid and preferably immune to the transducing phage, e.g., with a defective prophage. If the acceptor is also lysogenic, transfer may occur in both directions. If the acceptor is sensitive for the transducing phage, it will lyse, but the resulting phage may transduce a plasmid from the acceptor back to the donor (reversed transfer).

\section{Mixed cultures with sensitive acceptor}

Some instances of reversed transfer in which all transductants had the phage pattern of the donor are given in table III. Experiments 1-12 and 19-21 show that strains lysogenised with group-B phages are suitable donors, whereas lysogenisation with the group- $\mathrm{A}$ phages $3 \mathrm{~A}$ and $3 \mathrm{C}$ (experiments 13-18) did not cause detectable transfer. Among the phages of group B, phages 71 and 29 are better vectors than phages 80 and 88 . Transfer was also possible in mixed cultures when both strains were sensitive to the phage carried by the other partner (experiment 22). Both phages had the same titre on strain $3 \mathrm{AR}_{1}$ as on the lysogenised partner. Forty per cent of the transductants had the phage pattern of $3 \mathrm{AR}_{1}(71)$ and $60 \%$ that of $3 \mathrm{AR}_{1}(88)$, i.e., none was lysogenised by the transducing phage. Direct transfer of the Pc plasmid by phage 88 and of the Tc plasmid by phage 71 seems the simplest explanation. Reversed transfer is also possible. The high inoculum $\left(10^{6} \mathrm{cfu} / \mathrm{ml}\right)$ probably explains the survival of both strains (see fig. 6). 
TABLE III

Mixed cultures of phage-sensitive acceptor strains and donor strains carrying one of the $B$ phages $L_{10}, 71,29,80$ and 88 or the $A$ phages $3 A$ or $3 C$

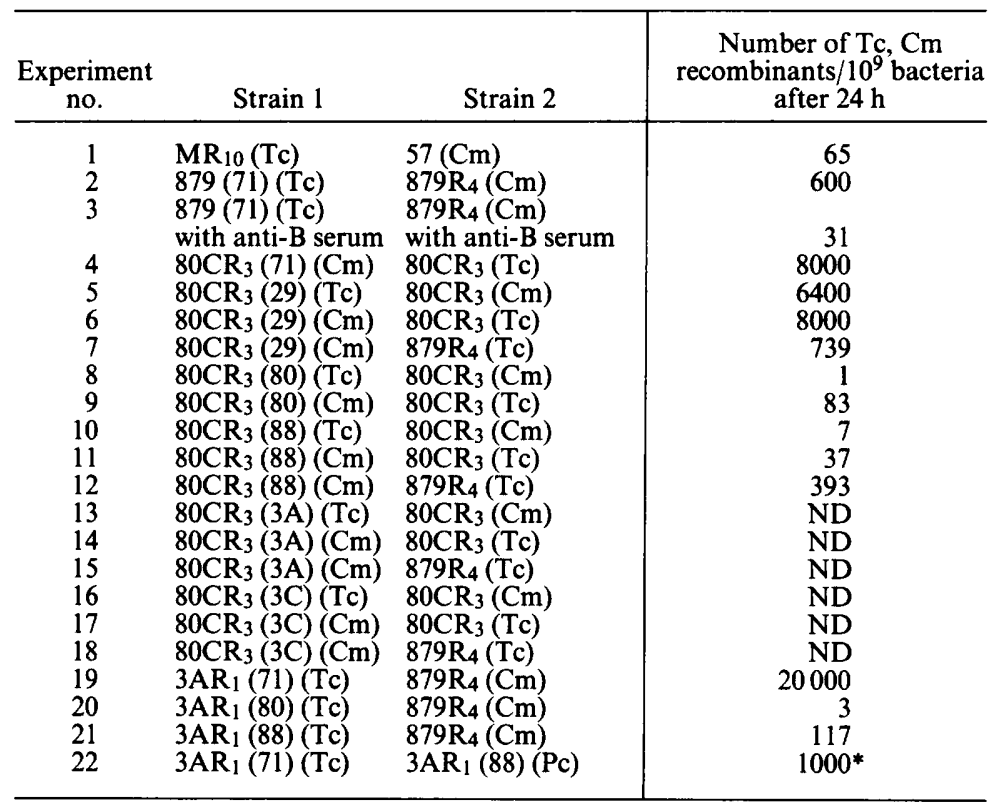

Abbreviations as in table I.

* Selection on Tc, Pc-agar plates.

\section{Mixed cultures of immune partners without restriction}

Experiments 1-7 in table IV were with mixtures of restriction-deficient strains carrying the same phage. Bidirectional transfer is possible but transfer in one direction often prevails (experiments 3 and 7). This is due to the low frequency of transduction of chromosomal markers or to a different transfer frequency of different markers (experiment 6; compare fig. 1). In experiments 8 and 9 there is immunity and no restriction; nevertheless there is no transfer.

\section{Partners with immunity and one-sided restriction}

In experiment 10 in table IV the frequency of transfer was low (e.g., experiment 1). Strain 879 carries the restriction enzyme Sau3A (Stobberingh, Schiphof and Sussenbach, 1977) and the Cm plasmid will be broken down on entrance. The strain is, however, a suitable donor of the Tc marker for the restriction-deficient strain $80 \mathrm{CR}_{3}$ which is the acceptor in this combination. Of 23 transductants, 21 had the phage pattern of $80 \mathrm{CR}_{3}$ (see also table V, experiments 6 and 8 ). 
TABLE IV

Mixed cultures of strains lysogenised with the same phage

\begin{tabular}{|c|c|c|c|c|c|c|c|}
\hline \multirow{2}{*}{$\begin{array}{c}\begin{array}{c}\text { Experiment } \\
\text { no. }\end{array} \\
\end{array}$} & \multirow[b]{2}{*}{ Strain 1} & \multirow[b]{2}{*}{ Strain 2} & \multicolumn{2}{|c|}{$\begin{array}{l}\text { EOP }(-\log ) \\
\text { relative to } \\
\text { strain }\end{array}$} & \multirow{2}{*}{$\begin{array}{c}\begin{array}{c}\text { Selection } \\
\text { for }\end{array} \\
\text { recombinants }\end{array}$} & \multicolumn{2}{|c|}{$\begin{array}{l}\text { Number of } \\
\text { recombinants } / 10^{9} \\
\text { bacteria after }\end{array}$} \\
\hline & & & $2 \rightarrow 1$ & $1 \rightarrow 2$ & & $5 \mathrm{~h}$ & $24 \mathrm{~h}$ \\
\hline $\begin{array}{r}1 \\
2 \\
3 \\
4 \\
5 \\
6 \\
7 \\
8 \\
9 \\
10\end{array}$ & $\begin{array}{l}879 \mathrm{R}_{4}(71)(\mathrm{Tc}) \\
879 \mathrm{R}_{4}(71)(\mathrm{Cm}) \\
879 \mathrm{R}_{4}(71) \mathrm{Em} \\
879 \mathrm{R}_{4}(71)(\mathrm{Cm}) \\
80 \mathrm{CR}_{3}(71)(\mathrm{Cm}) \\
879 \mathrm{R}_{4}(71)(\mathrm{Cm}) \\
879 \mathrm{R}_{4}(71)(\mathrm{Cm}) \\
57\left(\mathrm{~L}_{10}\right)(\mathrm{Cm}) \\
57\left(\mathrm{~L}_{11}\right)(\mathrm{Tc}) \\
80 \mathrm{CR}_{3}(71)(\mathrm{Cm})\end{array}$ & $\begin{array}{l}80 \mathrm{CR}_{3}(71)(\mathrm{Cm}) \\
879(71)(\mathrm{Tc}) \\
80 \mathrm{CR}_{3}(71)(\mathrm{Cm}) \\
879 \mathrm{R}_{4}(71)(\mathrm{Tc}) \\
80 \mathrm{CR}_{3}(71)(\mathrm{Tc}) \\
80 \mathrm{CR}_{3}(71)(\mathrm{Tc}) \\
879 \mathrm{R}_{4}(71) \mathrm{Em} \\
57\left(\mathrm{~L}_{10}\right)(\mathrm{Tc}) \\
57\left(\mathrm{~L}_{11}\right)(\mathrm{Cm}) \\
879(71)(\mathrm{Tc})\end{array}$ & $\begin{array}{l}\text { I } \\
\text { I } \\
\text { I } \\
\text { I } \\
\text { I } \\
\text { I } \\
\text { I } \\
\text { I } \\
\text { I } \\
\text { I }\end{array}$ & $\begin{array}{l}\text { I } \\
\text { I } \\
\text { I } \\
\text { I } \\
\text { I } \\
\text { I } \\
\text { I } \\
\text { I } \\
\text { I } \\
\text { I }\end{array}$ & $\begin{array}{l}\text { Tc, Cm } \\
\text { Tc, Cm } \\
\text { Em, Cm } \\
\text { Tc, Cm } \\
\text { Tc, Cm } \\
\text { Tc, Cm } \\
\text { Em, Cm } \\
\text { Tc, Cm } \\
\text { Tc, Cm } \\
\text { Tc, Cm }\end{array}$ & $\begin{array}{l}2000 \leftrightarrow \\
2000 \leftrightarrow \\
1500 \leftarrow \\
1200 \\
4500 \\
2000 \leftarrow \\
89 \rightarrow \\
\text { ND } \\
\text { ND } \\
12 \leftarrow\end{array}$ & $\begin{array}{l}2000 \leftrightarrow \\
2000 \leftrightarrow \\
2000 \leftarrow \\
1800 \\
8000 \\
2000 \leftarrow \\
71 \rightarrow \\
\text { ND } \\
\text { ND } \\
23 \leftarrow\end{array}$ \\
\hline
\end{tabular}

I = immunity; arrows indicate the direction of transfer; other abbreviations as in table I. 


\section{One partner immune with a defective prophage}

Strain $80 \mathrm{CR}_{3}(\mathrm{~d} 71)(\mathrm{Tc})$ with a defective phage cannot act as donor but is a suitable immune acceptor for combinations with phage 71 as transducing phage. In fig. 1, the transfer in mixtures of the lysogenic strain $80 \mathrm{CR}_{3}(71)(\mathrm{Tc})$ with four partners is compared with that in mixtures with the defective lysogen $80 \mathrm{CR}_{3}(\mathrm{~d} 71)(\mathrm{Tc})$. In the first two experiments the frequency of unidirectional transfer to the defective lysogen is 10 times lower than that of bidirectional transfer with the complete lysogen. This also indicates that the Tc plasmid is transferred 10 times more effectively than the Cm plasmid (compare table VI). In the other two experiments the partners are restriction-deficient non-lysogenic acceptors causing reversed transfer with a lysogenic donor but no transfer with the defective lysogen.
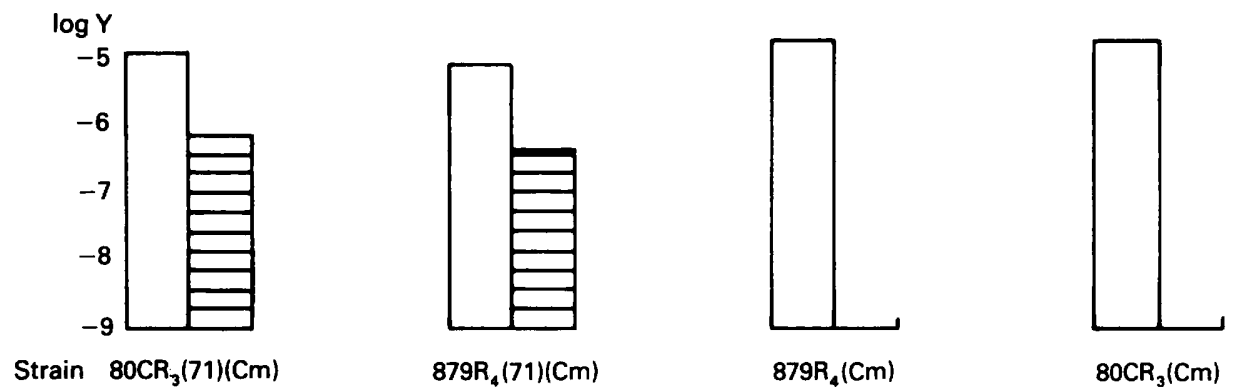

FIG. 1.-Frequency of transfer (Y) in mixtures of the indicated strains with strain $80 \mathrm{CR}_{3}(71)$ (Tc) (white columns) and the defective lysogen $80 \mathrm{CR}_{3}(\mathrm{~d} 71)$ (Tc) (hatched columns). $\mathrm{Y}=$ number of recombinants $\div$ total cell population.

\section{Strains with different phages}

As a measure of restriction (R) or immunity (I) of the partners, the negative logarithm of the efficiency of plating (EOP) relative to the homologous strain is given in columns 3 and 4 of table $\mathrm{V}$. In the first three cases, the strains have nearly the same modification and the phages show cross immunity. Transfer was unidirectional in experiments 1 and 2 . In experiment 2 the low FOT of the chromosomal Em marker may explain the one-way transfer. In experiment 3 transfer was not observed though the only difference from experiment 1 was the permutation of markers. This suggests that the relation of marker to transducing phage is an important condition for transfer. Experiments 4 and 5 are analogous to experiments 1 and 2. Experiments 6-8 illustrate the influence of the strong restriction in strain 57 for the group-II modification of strain $879 R_{4}$ (compare with experiments 1 and 4 ). Strain $879 R_{4}(71)(\mathrm{Cm})$ is lysed by phage $L_{11}$, and the large number of phage particles produced causes reversed transfer and overcomes restriction. 


\section{TABLE V}

Mixed cultures with constructed strains, lysogenised with different phages and of constructed strains with multiply resistant strains

\begin{tabular}{|c|c|c|c|c|c|c|c|}
\hline \multirow{2}{*}{$\begin{array}{c}\text { Experiment } \\
\text { no. }\end{array}$} & \multirow[b]{2}{*}{ Strain 1} & \multirow[b]{2}{*}{ Strain 2} & \multicolumn{2}{|c|}{$\begin{array}{l}\text { EOP }(-\log ) \\
\text { relative to } \\
\text { strain }\end{array}$} & \multirow{2}{*}{$\begin{array}{l}\text { Selection for } \\
\text { recombinants }\end{array}$} & \multicolumn{2}{|c|}{$\begin{array}{c}\text { Number of } \\
\text { recombinants } / 10^{9} \\
\text { bacteria after }\end{array}$} \\
\hline & & & $2 \rightarrow 1$ & $1 \rightarrow 2$ & & $5 \mathrm{~h}$ & $24 \mathrm{~h}$ \\
\hline $\begin{array}{r}1 \\
2 \\
3 \\
4 \\
5 \\
6 \\
7 \\
8 \\
9 \\
10 \\
11 \\
12 \\
13\end{array}$ & $\begin{array}{l}80 \mathrm{CR}_{3}(71)(\mathrm{Cm}) \\
80 \mathrm{CR}_{3}(71)(\mathrm{Cm}) \\
80 \mathrm{CR}_{3}(71)(\mathrm{Tc}) \\
80 \mathrm{CR}_{3}(71)(\mathrm{Cm}) \\
80 \mathrm{CR}_{3}(71)(\mathrm{Cm}) \\
879 \mathrm{R}_{4}(71)(\mathrm{Cm}) \\
879 \mathrm{R}_{4}(71)(\mathrm{Cm}) \\
879 \mathrm{R}_{4}(71)(\mathrm{Cm}) \\
80 \mathrm{CR}_{3}(71)(\mathrm{Cm}) \\
80 \mathrm{CR}_{3}(71)(\mathrm{Cm}) \\
80 \mathrm{CR}_{3}(71)(\mathrm{Cm}) \\
57\left(\mathrm{~L}_{10}\right) \mathrm{Sm} \\
57\left(\mathrm{~L}_{10}\right) \mathrm{Sm}\end{array}$ & $\begin{array}{l}57\left(\mathrm{~L}_{11}\right)(\mathrm{Tc}) \\
57\left(\mathrm{~L}_{11}\right) \mathrm{Em} \\
57\left(\mathrm{~L}_{11}\right)(\mathrm{Cm}) \\
57\left(\mathrm{~L}_{10}\right)(\mathrm{Tc}) \\
57\left(\mathrm{~L}_{10}\right) \mathrm{Em} \\
57\left(\mathrm{~L}_{11}\right)(\mathrm{Tc}) \\
57\left(\mathrm{~L}_{11}\right) \mathrm{Em} \\
57\left(\mathrm{~L}_{10}\right)(\mathrm{Tc}) \\
\mathrm{MR}_{8}(\mathrm{Tc}) \\
\mathrm{MR}_{10}(\mathrm{Em}) \\
\mathrm{MR}_{10}(\mathrm{Tc}) \\
\mathrm{MR}_{10}(\mathrm{Tc}) \\
\mathrm{MR}_{10}(\mathrm{Em})\end{array}$ & $\begin{array}{l}6, I^{*} \\
6, I \\
6, I \\
1 \\
1 \\
1 \\
1 \\
7, I \\
0 \\
0 \\
0 \\
\text { I } \\
\text { I }\end{array}$ & $\begin{array}{l}6, \mathrm{I} \\
6, \mathrm{I} \\
6, \mathrm{I} \\
5, \mathrm{I} \\
5, \mathrm{I} \\
7, \mathrm{R} \\
7, \mathrm{R} \\
7, \mathrm{R} \\
6 \\
6 \\
6 \\
\mathrm{I} \\
\mathrm{I}\end{array}$ & $\begin{array}{l}\text { Tc, Cm } \\
\mathrm{Cm}, \mathrm{Em} \\
\mathrm{Tc}, \mathrm{Cm} \\
\text { Tc, Cm } \\
\mathrm{Cm}, \mathrm{Em} \\
\text { Tc, Cm } \\
\mathrm{Cm}, \mathrm{Em} \\
\text { Tc, Cm } \\
\text { Tc, Cm } \\
\text { Em, Cm } \\
\text { Tc, Cm } \\
\text { Tc, Sm } \\
\text { Em, Sm }\end{array}$ & $\begin{array}{l}249 \rightarrow \\
133 \rightarrow \\
N D \\
140 \rightarrow \\
432 \rightarrow \\
11 \rightarrow \\
2 \leftrightarrow \\
4 \rightarrow \\
2 \rightarrow \\
29 \leftrightarrow \\
1 \leftarrow \\
6 \leftarrow \\
28 \leftarrow\end{array}$ & $\begin{array}{c}198 \rightarrow \\
106 \rightarrow \\
\mathrm{ND} \\
197 \rightarrow \\
100 \rightarrow \\
2 \rightarrow \\
\mathrm{ND} \\
\mathrm{ND} \\
4 \rightarrow \\
190 \rightarrow \\
48 \rightarrow \\
20 \leftarrow \\
43 \leftarrow\end{array}$ \\
\hline
\end{tabular}

EOP $=$ efficiency of plating (see text); other abbreviations as in table IV.

$* 6, I=$ Decrease of EOP by a factor of $10^{-6}$ because of cross immunity; $7, \mathrm{R}=$ decrease of EOP by a factor $10^{-7}$ because of restriction; $1=$ decrease of EOP by a factor $10^{-1}$ for unknown reason. 
Combinations of wild-type strains with constructed strains

Such combinations are often inefficient due to restriction of the wild type, unless the wild type is a good donor. Only 10 out of 24 combinations yielded recombinants. Some instances are shown in table V (experiments 9-13). In experiment 10 transfer was bidirectional at $5 \mathrm{~h}$, but because strain $80 \mathrm{CR}_{3}(71)$ $(\mathrm{Cm})$ is sensitive to phage $\mathrm{L}_{10}$ the transductants at $24 \mathrm{~h}$ were all due to reversed transfer.

\section{Kinetics of transfer}

Transfer in mixed culture by transduction obviously depends on phage production by the donor strain and phage adsorption by the acceptor. In a pure culture of a lysogenic strain (growth rate $\mu$ ) a small fraction (a) of the bacteria $\left(\mathrm{N}_{t}\right)$ will lyse with burst size $\mathrm{b}$. The concentration of phage $(\mathrm{P})$ will rise at a rate $d \mathrm{P} / d t=\mathrm{ab} \mu \mathrm{N}_{t}$ (see appendix), until adsorption (with coefficient $\mathrm{k}$ ) balances production. The free phage concentration will tend to a maximum value of $\mathrm{P}_{m}=\mathrm{ab} \mu / \mathrm{k}$ and decrease only when phage production stops in the stationary phase (fig. 2).

Table VI shows the values of $a, b, \mu, k$ and $\mathrm{P}_{m}$ for several strains. The values of $\mathrm{k}$ were determined with phage 71 propagated on strain PS 71 . Some values for induced lysates were determined and differed only slightly from those in table VI. The phage concentration in uninduced lysates was too low for reliable adsorption experiments to be performed. The adsorption coefficient influences adsorption rate. When $\mathrm{N}$ increases, the fraction of adsorbed phage $\left(\mathrm{PkN}_{t}\right)$ is high even when $\mathrm{k}$ is low.

From the values given in table VI the amount of phage adsorbed to the acceptor strain in a mixed culture can be calculated (see appendix). The

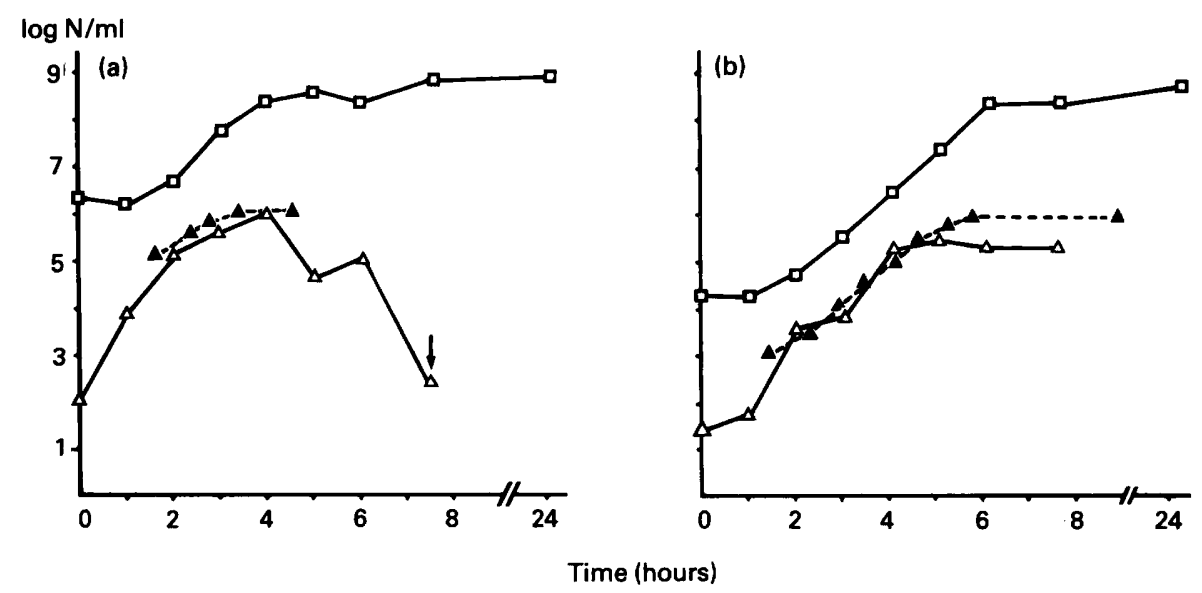

FIG. 2.-Concentration of free phage $L_{10}$ in a pure culture of lysogenic strain $M R_{10}$. (a) High inoculum; (b) low inoculum. $\square=\mathrm{cfu} ; \Delta=$ pfu experimental; $\Delta=$ pfu calculated (see appendix) for $\mu=1.8$, $\mathrm{ab}=2 \cdot 10^{-2}$ and $\mathrm{k}=10^{-9}$. The arrow indicates that the value is lower than the limit of detection drawn. 
TABLE VI

Parameters of transfer

\begin{tabular}{|c|c|c|c|c|c|c|c|}
\hline \multirow[b]{2}{*}{ Strain no. } & \multirow[b]{2}{*}{$\mu$} & \multirow[b]{2}{*}{ k } & \multirow[b]{2}{*}{ a } & \multirow[b]{2}{*}{ b } & \multirow[b]{2}{*}{$\log P_{m}$} & \multicolumn{2}{|c|}{ FOT* to strain } \\
\hline & & & & & & $80 \mathrm{CR}_{3}(71)$ & $879 R_{4}(71)$ \\
\hline $80 \mathrm{CR}_{3}(71)(\mathrm{Tc})$ & 0.90 & $1 \cdot 5$ & $3 \cdot 2$ & 31 & 6.00 & 610 & 610 \\
\hline $80 \mathrm{CR}_{3}(71)(\mathrm{Cm})$ & 1.07 & 6.6 & $2 \cdot 2$ & 33 & $5 \cdot 29$ & 250 & 250 \\
\hline $80 \mathrm{CR}_{3}(\mathrm{~d} 71)(\mathrm{Tc})$ & 0.65 & 6.6 & $\ldots$ & $\ldots$ & $\ldots$ & $\cdots$ & . \\
\hline $80 \mathrm{CR}_{3}(\mathrm{~d} 71)(\mathrm{Cm})$ & 0.94 & 6.9 & $\ldots$ & $\ldots$ & & . & \\
\hline $879 \mathrm{R}_{4}(71)(\mathrm{Tc})$ & $1 \cdot 20$ & 2.9 & 0.6 & 19 & 4.90 & 61 & 120 \\
\hline $879 \mathrm{R}_{4}(71)(\mathrm{Cm})$ & 1.08 & $1 \cdot 0$ & $1 \cdot 3$ & 25 & $5 \cdot 77$ & 8 & 6 \\
\hline
\end{tabular}

* FOT (frequency of transduction, $10^{6}$ ) was determined with phage from the strains in the first column, induced with mitomycin.

$\mu=$ Growth rate (per hour); $\mathrm{k}=$ adsorption coefficient of phage $71\left(10^{9}\right.$ per $\left.\mathrm{min}\right) ; \mathrm{a}=$ fraction of cells lysed $\left(10^{3}\right) ; b=$ burst size; $P_{m}=$ calculated maximum concentration of phage. Other abbreviations as in table I.

number of transductants depends on the fraction of adsorbed phage particles carrying and injecting the marker, i.e., on a factor comparable to FOT. This value is also given in table VI. The FOT of lysates of strains $57\left(\mathrm{~L}_{10}\right)$ and 57 $\left(\mathrm{L}_{11}\right)$ to the homologous strain was only $1 \times 10^{-6}$.

Fig. 3a shows the kinetics of transfer in a mixed culture. Free phage is maximal at $3 \mathrm{~h}$; transductants first appear at $2 \mathrm{~h}$ and reach a maximum between 4 and $6 \mathrm{~h}$, when phage production stops. With a lower inoculum (fig. $3 \mathrm{~b}$ ) the process is slower. Antiphage serum neutralises phage (fig. 3c) until the antibody is broken down by bacterial proteases. In fig. 4 the calculated values for free and adsorbed phage and for the number of transductants are also shown.

\section{Kinetics of unidirectional transfer}

A mixed culture with a defective lysogenic acceptor and only one phage seemed more suitable to test the mathematical model than the example in fig.
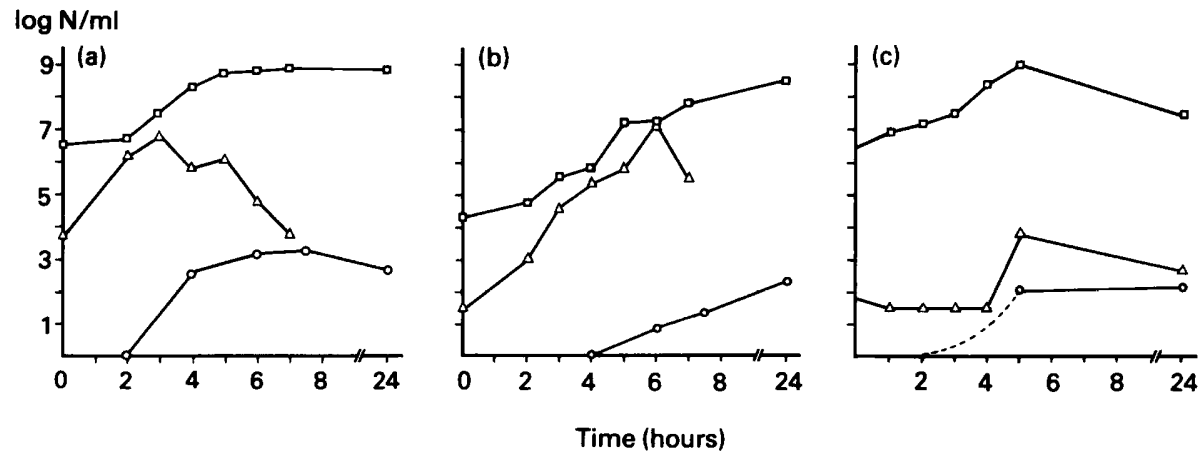

FIG. 3.-Resistance transfer in a mixed culture with bidirectional transfer: strain 879 (71) (Tc) with strain 879R4 (71) (Cm). (a) High inoculum; (b) low inoculum; (c) as (a) with $10 \%$ anti-phage serum. $\square=\mathrm{cfu}$; $\Delta=$ pfu; $\mathrm{o}=$ tranductants. 
4. In unidirectional systems both partners and transductants were counted separately on selective media and phage was counted as before. An instance is given in fig. 5 (omitting the separate growth curves of the partners which ran slightly below the total count). The number of transductants was in reasonable agreement with the calculated values (figs $5 \mathrm{a}$ and $5 \mathrm{~b}$ ). At a lower temperature (fig. 5d) transfer was slower but continued after $8 \mathrm{~h}$. Addition of mitomycin C at a concentration of $0.01 \mu \mathrm{g} / \mathrm{ml}$ caused an increased production of phage and a 10-fold increase of transductants (fig. 5c). As $\mathrm{P}_{m}$ had increased 16-fold it was assumed that the fraction of bacteria lysing (a) had increased. Separate experiments had shown that increased phage production did not begin until about 90 min after adding mitomycin $\mathrm{C}$. The number of transductants was calculated by using ' $a$ ' for times from 0 to 90 min and 16 a for times longer than $90 \mathrm{~min}$. Similar results were obtained with four other systems.

\section{Kinetics of reversed transfer}

Fig. 6 gives an instance of reversed transfer. The free phage concentration and $\mathrm{P}_{m}$ were high and transductants appeared early in large numbers. The viable counts of the sensitive strain reached a maximum after $3 \mathrm{~h}$ when lysis compensated growth $(\mu-\mathrm{kP}=0)$. With decreasing numbers of this partner the chance for phage adsorption decreases. The reduced phage production by the

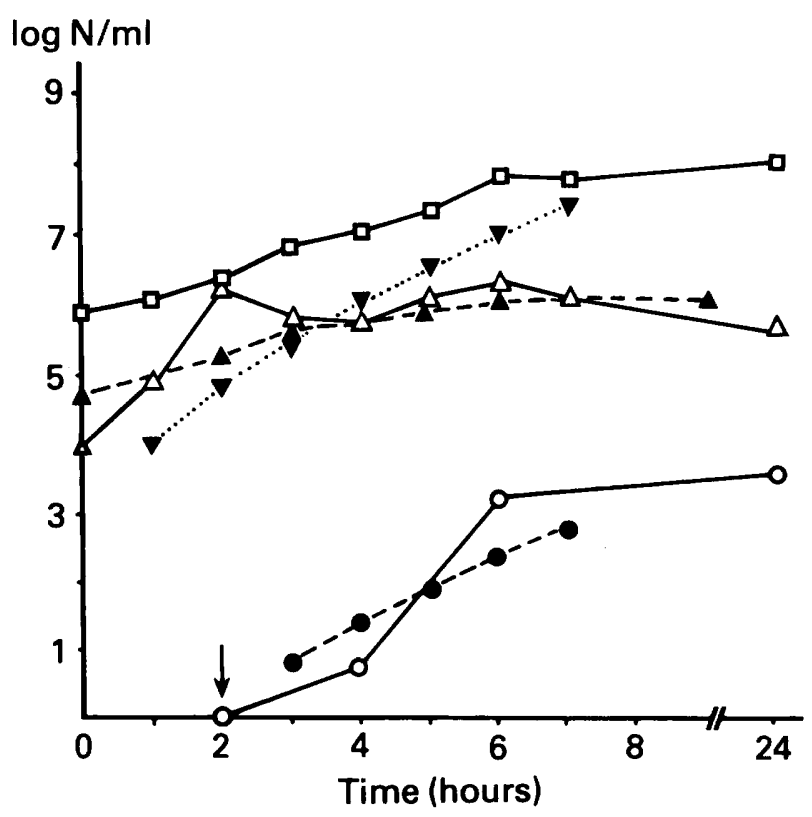

FIG. 4.-Mixed culture of strain $80 \mathrm{CR}_{3}(71)(\mathrm{Tc})$ with strain $80 \mathrm{CR}_{3}(71)(\mathrm{Cm})$. $\square=\mathrm{cfu}$; $\Delta=\mathrm{pfu}$; $\circ=$ transductants $(\mathrm{T}) ; \Delta=$ pfu calculated; $\nabla=$ adsorbed phage, calculated; $\bullet=\mathrm{T}$ calculated. The arrow indicates that the value is lower than the limit of detection drawn. 
$\log \mathrm{N} / \mathrm{ml}$
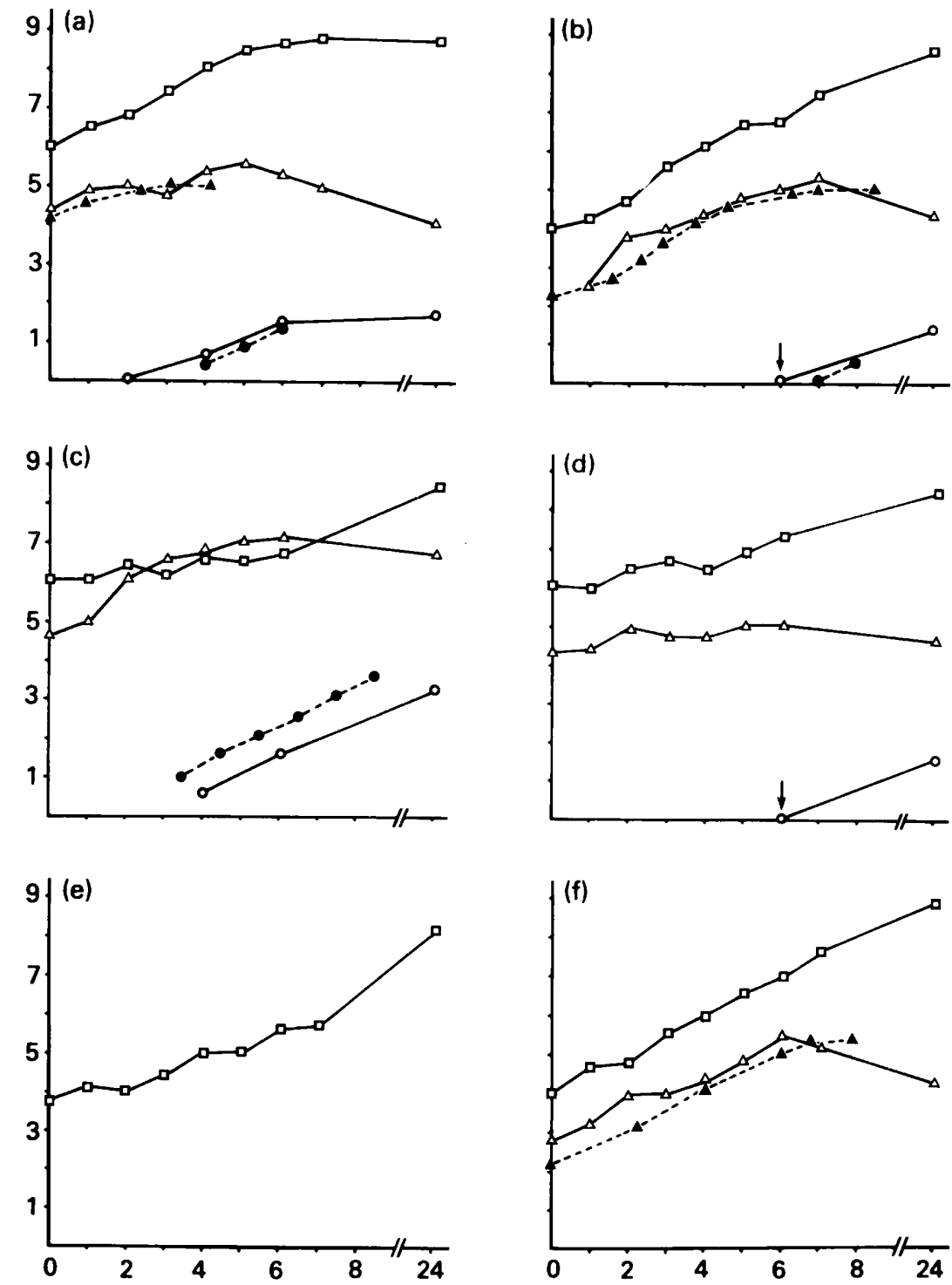

Time (hours)

Fig. 5.-Unidirectional transfer in mixed culture of strain $879 \mathrm{R}_{4}(71)(\mathrm{Cm})$ with strain $80 \mathrm{CR}_{3}(\mathrm{~d} 71)(\mathrm{Tc})$. (a) High inoculum; (b) low inoculum; (c) as (a) with mitomycin; (d) as (a) at $30^{\circ} \mathrm{C}$; (e) pure culture of $80 \mathrm{CR}_{3}$ (d71) (Tc), low inoculum; (f) pure culture of $879 \mathrm{R}_{4}(71)(\mathrm{Cm})$, low inoculum. $\mathrm{a}=\mathrm{cfu} ; \Delta=\mathrm{pfu} ; \Delta=\mathrm{pfu}$ calculated; $\circ=$ transductants $(\mathrm{T}) ; \bullet=\mathrm{T}$ calculated. The arrow indicates that the value is lower than the limit of detection drawn. 


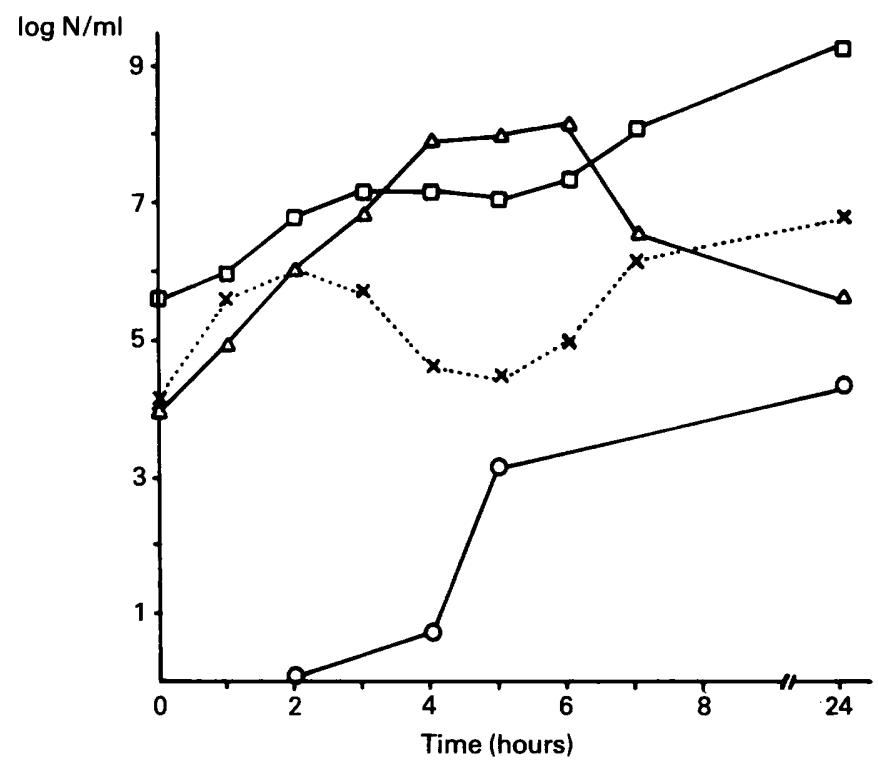

Fig. 6. - Reversed transfer in mixed culture of strain $80 \mathrm{CR}_{3}(71)(\mathrm{Cm})$ and strain $879 \mathrm{R}_{4}(\mathrm{Tc})$ (pure-culture controls omitted). $\mathbf{D}=\mathrm{cfu} ; \times=\mathrm{cfu}$ on medium with tetracycline; $\Delta=\mathrm{pfu} ; \circ=$ transductants.

donor strain at the end of the exponential phase permits survival and even some growth of the sensitive strain. Even some primary transductants might survive.

\section{Experiments in mice and on human skin}

Table VII shows that recombinants were detected in local lesions of mice injected with two strains. The results of experiments on human skin are also presented in table VII.

\section{DisCUSSION}

Transfer in mixed culture by general transduction was regularly obtained with constructed strains. The mathematical model seems to describe the kinetics quite well. Among the parameters the FOT is by far the most important. The low transfer in systems with strain 57 (table VI) is explained by the low FOT. The FOT obviously depends on marker as well as on phage (table III) and includes more than marker size or copy number alone.

The conditions for transfer by general transduction will not often be met in mixed cultures of a random combination of wild-type strains. One of the strains should carry a plasmid and a phage of serogroup B, which can transduce the plasmid with a sufficiently high FOT. The other strain should not be restrictive or have only weak restriction for the donor modification and should not contain an incompatible plasmid. In nature each strain will be confronted 
TABLE VII

Transfer of resistance plasmids in vivo

\begin{tabular}{|c|c|c|c|c|c|c|}
\hline Strain 1 & Strain 2 & $\begin{array}{l}\text { Inoculum } \\
\left(\log _{10} \mathrm{cfu}\right)\end{array}$ & $\begin{array}{c}\text { Time } \\
\text { (h) }\end{array}$ & $\begin{array}{c}\text { Harvest } \\
\left(\log _{10} \mathrm{cfu}\right)\end{array}$ & & $\begin{array}{l}\text { umber of } \\
\text { Tc, Cm } \\
\text { mbinants* }\end{array}$ \\
\hline \multicolumn{7}{|l|}{ In mice $\dagger$} \\
\hline $80 \mathrm{CR}_{3}(71)(\mathrm{Tc})$ & $80 \mathrm{CR}_{3}(71)(\mathrm{Cm})$ & $6 \cdot 7$ & 96 & $7 \cdot 1$ & 12 & (929) \\
\hline $80 \mathrm{CR}_{3}(71)(\mathrm{Tc})$ & $879 R_{4}(71)(\mathrm{Cm})$ & 6.7 & $\begin{array}{r}72 \\
144 \\
216\end{array}$ & $\begin{array}{l}7 \cdot 5 \\
7 \cdot 3 \\
7 \cdot 6\end{array}$ & $\begin{array}{l}9 \\
4 \\
2\end{array}$ & $\begin{array}{l}(257) \leftarrow \\
(190) \leftarrow \\
(111) \leftarrow\end{array}$ \\
\hline $80 \mathrm{CR}_{3}(71)(\mathrm{Cm})$ & $80 \mathrm{CR}_{3}(\mathrm{Tc})$ & 6.9 & 96 & $7 \cdot 1$ & 18 & $(1384) \leftrightarrow$ \\
\hline $80 \mathrm{CR}_{3}(71)(\mathrm{Cm})$ & $57\left(\mathrm{~L}_{10}\right)(\mathrm{Tc})$ & $6 \cdot 4$ & $\begin{array}{r}96 \\
168\end{array}$ & $\begin{array}{l}8 \cdot 3 \\
7 \cdot 0\end{array}$ & $\begin{array}{l}1 \\
1\end{array}$ & $\begin{array}{r}(5) \leftarrow \\
(102) \leftarrow\end{array}$ \\
\hline $80 \mathrm{CR}_{3}(71)(\mathrm{Cm})$ & $57\left(\mathrm{~L}_{11}\right)(\mathrm{Tc})$ & $6 \cdot 4$ & $\begin{array}{r}96 \\
168\end{array}$ & $\begin{array}{l}8 \cdot 1 \\
6 \cdot 9\end{array}$ & $\mathrm{ND}$ & $\begin{array}{l}(<8) \\
(118) \leftarrow\end{array}$ \\
\hline \multicolumn{7}{|l|}{ On human skin } \\
\hline $80 \mathrm{CR}_{3}(71)(\mathrm{Tc})$ & $80 \mathrm{CR}_{3}(71)(\mathrm{Cm})$ & $6 \cdot 6$ & 72 & $8 \cdot 2$ & 176 & (1173) \\
\hline $80 \mathrm{CR}_{3}(71)(\mathrm{Tc})$ & $879 \mathrm{R}_{4}(71)(\mathrm{Cr})$ & $6 \cdot 8$ & 48 & 6.9 & 33 & $(40491) \rightarrow$ \\
\hline $80 \mathrm{CR}_{3}(71)(\mathrm{Cm})$ & $879 \mathrm{R}_{4}(71)(\mathrm{Tc})$ & $6 \cdot 7$ & 48 & $7 \cdot 4$ & 34 & $(13906) \leftrightarrow$ \\
\hline $80 \mathrm{CR}_{3}(71)(\mathrm{Tc})$ & $80 \mathrm{CR}_{3}(\mathrm{Cm})$ & $6 \cdot 8$ & 48 & $7 \cdot 7$ & 25 & $(5112) \leftarrow$ \\
\hline $879 \mathrm{R}_{4}(71)(\mathrm{Tc})$ & $879 R_{4}(\mathrm{Cm})$ & $6 \cdot 9$ & 48 & $7 \cdot 7$ & 247 & $(50511) \leftarrow$ \\
\hline $\mathrm{MR}_{10}$ & $80 \mathrm{CR}_{3}(71)(\mathrm{Cm})$ & $6 \cdot 3$ & 48 & $7 \cdot 5$ & & $(613) \leftarrow$ \\
\hline $57\left(\mathrm{~L}_{10}\right)(\mathrm{Tc})$ & $80 \mathrm{CR}_{3}(71)(\mathrm{Cm})$ & $6 \cdot 3$ & 48 & $7 \cdot 5$ & 3 & $(920) \leftarrow$ \\
\hline $57\left(\mathrm{~L}_{11}\right)(\mathrm{Tc})$ & $80 \mathrm{CR}_{3}(71)(\mathrm{Cm})$ & $6 \cdot 3$ & 48 & $7 \cdot 8$ & 29 & $(4448) \leftarrow$ \\
\hline $3 \mathrm{AR}_{1}(7 \mathrm{l})(\mathrm{Tc})$ & $3 \mathrm{AR}_{1}(88)(\mathrm{Pc})$ & $6 \cdot 0$ & 48 & $6 \cdot 7$ & & $(44990) \leftarrow$ \\
\hline
\end{tabular}

Abbreviations as in Table IV.

* In parentheses, per $10^{9} \mathrm{cfu}$.

+ Mean of three mice.

$\ddagger$ Selection on Tc, Pc agar plates.

by enough other strains to permit transfer by general transduction during some encounters. Reversed transfer may be a mechanism by which a new strain entering an environment (e.g., the nose) can be lysed by a resident phage but still yield a resistance marker to the resident strain.

The number of bacteria isolated from local lesions in mice is obviously only a minor fraction of the total population formed by cell division, the greater part having been killed or removed by defence factors. The number of recombinants is low, even when calculated for a population of $10^{9}$ bacteria. In some experiments (table VII, experiments 4 and 5) one partner (strain 57) predominated in the lesion; this suggested that some form of selection occurred in the lesion but not in vitro. The number of recombinants decreased with time (table VII, experiment 2) suggesting that removal of recombinants also takes place. Such recombinants could of course be selected by suitable antibacterial therapy.

The yield of transductants from human skin was higher than from lesions in mice. Although the flora recovered from the skin is obviously an underestimation, the difference is probably real, because the bacteria are present in a very thin layer and $10^{8}$ bacteria/site represent $2.5 \times 10^{7}$ bacteria $/ \mathrm{cm}^{2}$. The distance to be travelled by phage is then at least equal to that in a culture with $10^{9}$ 
bacteria/ml. Such surface populations, skin, nose, Spitz-Holter valves, intravenous catheters, are ideal sites for transfer. These data suggest that general transduction is an important mechanism of resistance transfer between strains of $S$. aureus in vitro as well as in vivo.

\section{Appendix}

\section{MATHEMATICAL MODEL OF TRANSFER IN MIXED CULTURES}

Free phage $(\mathrm{P})$ in lysogenic cultures

Assumptions. Growth is exponential: where $\mathrm{N}=$ number of bacteria, $\mu=$ growth rate, $t=$ time

$$
d \mathrm{~N} / d t=\mu \mathrm{N} \text { and } \mathrm{N}_{t}=\mathrm{N}_{o} e^{\mu t}
$$

Phage production: a small fraction (a) of the bacterial population lyses at division with a mean burst size (b)

$$
d \mathrm{P} / d t=\mathrm{ab} d \mathrm{~N} / \mathrm{dt}=\mathrm{ab} \mu \mathrm{N}_{o} e^{\mu t}=\mathrm{ab} \mu \mathrm{N}_{t} .
$$

Phage adsorption:

$$
d \mathrm{P} / d t=-\mathrm{kPN}_{t}=-\mathrm{kPN}_{o} e^{\mu t} .
$$

Free phage as $f(t)$ : assumptions 2 and 3 result in

$$
d \mathrm{P} / d t=\mathrm{ab} \mu \mathrm{N}_{t}-\mathrm{kPN}_{t}=\left(\frac{\mathrm{ab} \mu}{\mathrm{k}}-\mathrm{P}\right) \mathrm{kN}_{t}
$$

for $d \mathrm{P} / d t=0$, $\mathrm{P}$ will be maximal at $\mathrm{P}_{m}=\frac{\mathrm{ab} \mu}{\mathrm{k}}$.

In consequence

$$
d \mathrm{P} / d t=\left(\mathrm{P}_{m}-\mathrm{P}\right) \mathrm{kN}_{t}, \frac{d \mathrm{P}}{\mathrm{P}_{m}-\mathrm{P}}=\mathrm{kN}_{t} d t
$$

and

$$
\frac{d\left(\mathrm{P}_{m}-\mathrm{P}\right)}{\mathrm{P}_{m}-\mathrm{P}}=-\mathrm{kN}_{t} d t \text { and } \ln \left(\mathrm{P}_{m}-\mathrm{P}\right)=-\frac{\mathrm{k}}{\mu} \mathrm{N}_{t}+\mathrm{C} \text {. }
$$

At $t=0, \mathrm{~N}_{t}=\mathrm{N}_{o}, \mathrm{P}=\mathrm{P}_{o}$ and $\mathrm{C}$ will be

and

$$
\mathrm{C}=\ln \left(\mathrm{P}_{m}-\mathrm{P}_{o}\right)+\frac{\mathrm{k}}{\mu} \mathrm{N}_{o}
$$

$$
\begin{array}{ll}
\text { and } & \ln \frac{\left(\mathrm{P}_{m}-\mathrm{P}\right)}{\left(\mathrm{P}_{m}-\mathrm{P}_{o}\right)}=-\frac{\mathrm{k}}{\mu}\left(\mathrm{N}_{t}-\mathrm{N}_{o}\right) \\
\text { or } & \left(\mathrm{P}_{m}-\mathrm{P}\right)=\left(\mathrm{P}_{m}-\mathrm{P}_{o}\right) e^{\frac{\mathrm{k}}{\mu}\left(\mathrm{N}_{t}-\mathrm{N}_{o}\right)} .
\end{array}
$$


Discussion. During exponential growth and if $\mathrm{P}_{o}=a b \mathrm{~N}_{o}, \mathrm{P}_{t}$ will increase according to $a b N_{t}$ and flatten off rather abruptly to the level of $\mathrm{P}_{m}$, which will be maintained as long as exponential growth continues (fig. 2). If $\mathrm{P}_{o}<\mathrm{abN} \mathrm{N}_{o}$ or $\mathrm{P}_{o}>\mathrm{abN} \mathrm{N}_{o}$ the initial rise of $\mathrm{P}_{t}$ will be faster or slower till abN $\mathrm{N}_{t}$ is reached.

If the stationary phase $\left(\mathrm{N}=\mathrm{N}_{m}\right)$ implies $\mu=0$ and phage production is indeed linked to division, the only remaining process will be adsorption and $\mathrm{P}_{t}$ will decrease steeply as $1 n \mathrm{P}_{t} / \mathrm{P}_{m}=-\mathrm{kN}_{m} t$.

If the stationary phase masks cryptic growth $\left(\mu_{s}\right)$ equalling death (d) with $\mathrm{dN} / \mathrm{dt}=0=\left(\mu_{s}-\mathrm{d}\right) \mathrm{N}_{m}$, then $\mathrm{P}_{t}$ will tend to a constant value of $\mathrm{P}_{s}=\mathrm{ab} \mu_{s} / \mathrm{k}$. A gradual change to the stationary phase will cause a gradual decrease from $P_{m}$ to $\mathrm{P}_{s}$. If $\mu_{s}$ decreases (with $\mathrm{d}$ ) the decrease of $\mathrm{P}_{t}$ will continue. If $\mathrm{P}$ is also adsorbed to dead bacteria, $\mathrm{P}_{s}$ will decrease further.

\section{Free and adsorbed phage particles in mixed cultures}

Notations: strains $i$ and $j$ carrying $\mathrm{P}_{i}$ and $\mathrm{P}_{j} . \mathrm{N}_{i o}, \mathrm{~N}_{j o}, \mathrm{P}_{i o}$ and $\mathrm{P}_{j o}$ numbers at $t=0$. Production: $d \mathbf{P}_{i} / d t=\mathrm{a}_{i} \mathrm{~b}_{i} d \mathrm{~N}_{i} / d t$. Adsorption: $d \mathbf{P}_{i} / d t=-\mathrm{k}_{i} \mathrm{P}_{i} \mathbf{N}_{i}-\mathrm{k}_{i j} \mathbf{P}_{i} \mathbf{N}_{j}$ if $\mathrm{k}_{i}$ and $\mathrm{k}_{i j}$ are adsorption coefficients of $\mathrm{P}_{i}$ to bacteria $i$ and $j$. For phage $\mathrm{P}_{j}$ the same symbols with indices $j$.

Assumption. $\mu_{i}=\mu_{j}=\mu$. Free phage $\mathrm{P}_{i}$ will develop with time as

$$
d \mathrm{P}_{i} / d t=\left(\mathrm{a}_{i} \mathrm{~b}_{i} \mu \mathrm{N}_{i o}-\mathrm{k}_{i} \mathrm{P}_{i} \mathrm{~N}_{i o}-\mathrm{k}_{i j} \mathrm{P}_{i} \mathrm{~N}_{j o}\right) e^{\mu t} .
$$

When we write $\mathrm{A}_{i}=\mathrm{k}_{i} \mathrm{~N}_{i o}+\mathrm{k}_{i j} \mathrm{~N}_{j o}$ and $\mathrm{B}_{i}=\mathrm{a}_{i} \mathrm{~b}_{i} \mathrm{~N}_{i o}$ this gives

$$
d \mathrm{P}_{i} / d t=\left(\mu \mathrm{B}_{i}-\mathrm{A}_{i} \mathrm{P}_{i}\right) e^{\mu t} \text { and } \mathrm{P}_{i m}=\mu \mathrm{B}_{i} / \mathrm{A}_{i}
$$

and

$$
\mathrm{P}_{i}=\mathrm{P}_{i m}-\left(\mathrm{P}_{i m}-\mathrm{P}_{i o}\right) e^{\frac{\mathrm{A}_{i}}{\mu}\left(e^{\mu t}-1\right)} .
$$

$\mathrm{P}_{i}$ will adsorb to strain $j$ as

$$
\frac{d \mathrm{P}_{i}^{a d s j}}{d t}=\mathrm{k}_{i j} \mathrm{~N}_{j o} e^{\mu t} \mathrm{P}_{i}=\mathbf{k}_{i j} \mathrm{~N}_{j o} e^{\mu t}\left\{\mathrm{P}_{i m}^{-}-\left(\mathrm{P}_{i m}^{-}-\mathrm{P}_{i o}\right) e^{\frac{\mathrm{A}_{i}}{\mu}\left(e^{\mu t}-1\right)}\right\} .
$$

With inocula from exponential cultures with $\mathrm{P}<\mathrm{P}_{m}, \mathrm{P}_{o}$ will be $a_{i} b_{i} \mathrm{~N}_{i o}$.

and

$$
\frac{d \mathrm{P}_{i}^{a d s j}}{d t}=\mathbf{k}_{i j} \mathrm{~N}_{j o}\left\{\frac{\mu \mathrm{B}_{i}}{\mathrm{~A}_{i}} e^{\mu t}-\left(\frac{\mu \mathrm{B}_{i}}{\mathrm{~A}_{i}}-\mathrm{B}_{i}\right) e^{\frac{\mathrm{A}_{i}}{\mu}\left(e^{\mu t}-1\right)} e^{\mu t}\right\}
$$

$$
\mathrm{P}_{\mathrm{i}}^{a d s j}=\mathbf{k}_{i j} \mathrm{~N}_{j o} \frac{\mathrm{B}_{i}}{\mathrm{~A}_{i}}\left\{e^{\mu t}+\left(\frac{\mu}{\mathrm{A}_{i}}-1\right) e^{\frac{\mathrm{A}_{i}}{\mu}\left({ }^{\mu \mu t}-1\right)}+\mathrm{C}\right\}
$$

at $t=0, \mathrm{P}_{i}^{a d s} j=0$ and $1+\left(\frac{\mu}{\mathrm{A}_{i}}-1\right)+\mathrm{C}=0$

and consequently

$$
\mathrm{P}_{i}^{a d s j}=\mathbf{k}_{i j} \mathbf{N}_{j o} \frac{\mathrm{B}_{i}}{\mathrm{~A}_{i}}\left\{\left(e^{\mu t}-1\right)+\left(\frac{\mu}{\mathrm{A}_{i}}-1\right)\left(e^{\frac{\mathrm{A}_{i}}{\mu}\left(e^{\mu t}-1\right)}-1\right)\right\}
$$


The term in parentheses gives the development of $\mathrm{P}_{i}$ with time $\left(f_{i}(t)\right)$; the first term is $\mathrm{P}_{i}$ adsorbed to strain $j$ as fraction of all $\mathrm{P}_{i}$ adsorbed. For $\mathbf{k}_{i}=\mathrm{k}_{j}$, $\mathrm{N}_{i o}=\mathrm{N}_{j o}=\frac{1}{2} \mathrm{~N}_{o}$ and $\mathrm{N}_{t}=\mathrm{N}_{i t}+\mathrm{N}_{j t}$ this gives

$$
\mathrm{P}_{i}^{a d s} j=\frac{1}{2} f(t)
$$

The number of transductants $\mathrm{T}_{i j}$ by $\mathrm{P}_{i}$ in $\mathrm{N}_{i}$ is a fraction FOT of $\mathrm{P}_{i}^{a d s} j$

$$
\mathrm{T}_{i j}=\mathrm{FOT}_{i} \mathrm{k}_{i j} \mathrm{~N}_{j o} \frac{\mathrm{B}_{i}}{\mathrm{~A}_{i}} f(t)
$$

\section{DisCUSSION}

As long as $\mathrm{N}_{i o}=\mathrm{N}_{j o}$ and all k's are equal $\mathrm{A}_{i}=\mathrm{A}_{j}$ and $\mathrm{f}_{i}(t)=\mathrm{f}_{j}(t)$. When phage production is different $\left(\mathrm{a}_{i} \mathrm{~b}_{i}=\mathrm{pa}_{j} \mathrm{~b}_{j}\right.$ and $\mathrm{B}_{i}=\mathrm{pB}_{j}$ the ratio of transductants will be

$$
\frac{\mathrm{T}_{i j}}{\mathrm{~T}_{j i}}=\frac{\mathrm{FOT}_{i} \cdot \mathrm{k} \cdot \mathrm{N}_{o} \cdot \mathrm{B}_{i} \cdot \mathrm{A} \cdot f(t)}{\mathrm{FOT}_{j} \cdot \mathrm{k} \cdot \mathrm{N}_{o} \mathrm{~B}_{j} \cdot \mathrm{A} \cdot f(t)}=\mathrm{p} \frac{\mathrm{FOT}_{i}}{\mathrm{FOT}_{j}}
$$

Transfer in one direction will prevail by a higher production of $\mathrm{P}_{i}$ higher a and/or $\mathrm{b}$ or by higher $\mathrm{FOT}_{i}$. When inocula differ $\left(\mathrm{N}_{i o}=\mathrm{qN}_{j o}\right)$ but other parameters are equal $f_{i}(t)$ will equal $f_{j}(t)$ as $\mathrm{A}_{i}=\mathrm{A}_{j}=(1+\mathrm{q}) \mathrm{kN}_{o}$. But as $\mathrm{B}_{i}=\mathrm{qB}_{j}$

$$
\frac{\mathrm{T}_{i j}}{\mathrm{~T}_{j i}}=\frac{\mathrm{k} \cdot \mathrm{N}_{o} \cdot \mathrm{q} \cdot \mathrm{B} \cdot \mathrm{A} \cdot \mathrm{FOT} \cdot f(t)}{\mathrm{k} \cdot q \mathrm{~N}_{o} \cdot \mathrm{B} \cdot \mathrm{A} \cdot \mathrm{FOT} \cdot f(t)}=1 .
$$

Though $\mathrm{q}$ times more $\mathrm{P}_{i}$ is formed the fraction adsorbed to $j$ is q times smaller.

\section{REFERENCES}

Adams, M. H. 1959. Bacteriophages. Interscience Publishers, New York.

ASHESHOV, E. H. AND WINKLER, K. C. 1966. Staphylococcus aureus strains in the ' $52,52 \mathrm{~A}, 80,81$ complex'. Nature, Lond., 209, 638.

Blair, J. E. AND Williams, R. E. O. 1961. Phage typing of staphylococci. Bull. Wld Hlth Org., 24, 771 .

JAROLMEN, H., Bondi, A. AND Crowell, R. L. 1965. Transduction of Staphylococcus aureus to tetracycline resistance in vivo. J. Bact., 89, 1286.

LACEY, R. W. 1971a. Transfer of tetracycline-resistance between strains of Staphylococcus aureus in mixed cultures. J. gen. Microbiol., 69, 229.

LACEY, R. W. $1971 b$. High-frequency transfer of neomycin resistance between naturally occurring strains of Staphylococcus aureus. J. med. Microbiol., 4, 73.

LACEY, R. W. AND RICHMOND, M. H. 1974. The genetic basis of antibiotic resistance in Staphylococcus aureus: the importance of gene transfer in the evolution of this organism in the hospital environment. Ann. N.Y. Acad. Sci., 236, 395.

Miles, A. A., MisRa, S. S. AND IRWIN, J. O. 1938. The estimation of the bactericidal power of the blood. J. Hyg., Camb., 38, 732.

NoRDSTRÖM, K., ForsGren, A. AND Cox, P. 1974. Prevention of bacteriophage adsorption to Staphylococcus aureus by immunoglobulin G. J. Virol., 14, 203.

NovicK, R. P. AND MORSE, S. I. 1967. In vivo transmission of drug resistance factors between strains of Staphylococcus aureus. J. exp. Med., 125, 45. 
RITZ, H. L. AND BALDWIN, J. N. 1958. Induction of penicillinase production in staphylococci by bacteriophage. Bact. Proc., 58, 40.

Singh, G., MaRPLeS, R. R. AND Kligman, A. M. 1971. Experimental Staphylococcus aureus infections in humans. J. invest. Derm., 57, 149.

Stobberingh, E. E., Schiphof, R. AND Sussenbach, J. S. 1977. Occurrence of a class II restriction endonuclease in Staphylococcus aureus. J. Bact., 131, 645.

STOBBERINGH, E. E. AND WINKLER, K. C. 1977. Restriction-deficient mutants of Staphylococcus aureus. J. gen. Microbiol., 99, 359.

STRASTERS, K. C. AND WINKLER, K. C. 1966. Viability of hospital staphylococci in air. Bact. Rev., 30, 674.

WinKLER, K. C. AND GROOTSEN, C. 1961. The relation of phage pattern and lysogenicity in the phage-typing of staphylococci of phage-group II. Antonie van Leeuwenhoek, 27, 225.

Winkler, K. C., De WaART, J., Grootsen, C., Zegers, B. J. M., Tellier, N. F. AND Ver Tregt, C. D. 1965. Lysogenic conversion of staphylococci to loss of $\beta$-toxin. J. gen. Microbiol., 39, 321.

WITTE, W. 1977. Transfer of drug-resistance-plasmids in mixed cultures of staphylococci. Zentbl. Bakt. ParasitKde, I Abt. Orig., 237, 147. 